\title{
Fluoride levels in deep aquifers of Makurdi, North-central, Nigeria: An Appraisal based on multivariate statistics and human health risk analysis
}

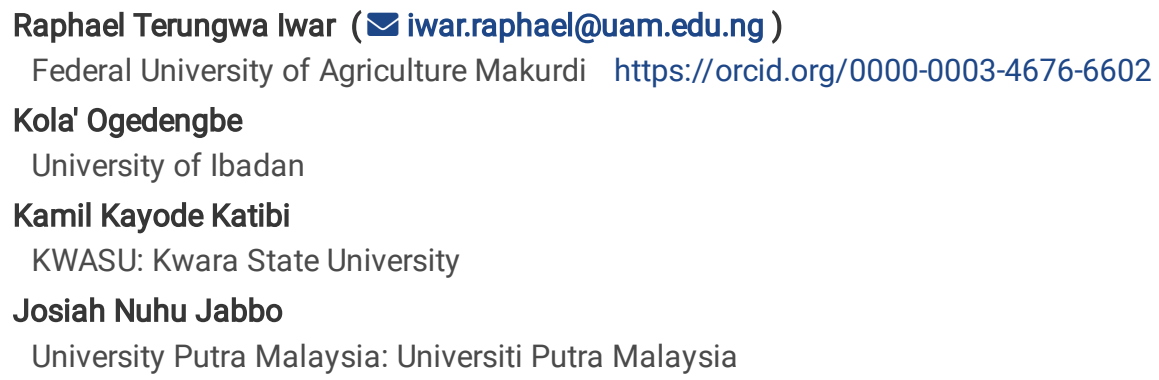

\section{Research Article}

Keywords: Groundwater, Fluoride Contamination, Principal Component Analysis, Correlation Analysis, Hazard Quotient

Posted Date: February 19th, 2021

DOI: https://doi.org/10.21203/rs.3.rs-216331/v1

License: (c) (i) This work is licensed under a Creative Commons Attribution 4.0 International License. Read Full License

Version of Record: A version of this preprint was published at Environmental Monitoring and Assessment on July 7th, 2021. See the published version at https://doi.org/10.1007/s10661-021-09230-8. 


\section{Abstract}

This study was conducted to investigate the ionic and fluoride concentrations in borehole water and its associated health risk potentials to residents of Makurdi town and its environs, Benue state, Nigeria. An aggregate of sixty-three (63) groundwater samples were retrieved from boreholes in twenty-one (21) diverse points within the study area and assessed for its physico-chemical composition with emphasis on fluoride content and health risk potentials following standard field and laboratory procedures. It was observed that fluoride content in the sampled water exceeded the stipulated safe limit of $1.5 \mathrm{mg} / \mathrm{L}$ in about $33.33 \%$ of the total samples and ranged from $0.34-2.06 \mathrm{mg} / \mathrm{L}$ with an average of $1.26 \pm 0.41 \mathrm{mg} / \mathrm{L}$. Moderate affirmative relationships were observed to exist between $\mathrm{F}^{-}$and $\mathrm{TDS} ; \mathrm{F}^{-}$and $\mathrm{EC} ; \mathrm{F}^{-}$and $\mathrm{Cl}^{-} ; \mathrm{F}^{-}$and $\mathrm{NO}_{3}{ }^{-}$in the water samples indicative of a common source pollution. Principal Component Analysis (PCA) revealed that high fluoride content in the water samples was associated with the dissolutions from quartzite and shale into the underlying deep aquifers. Fluoride risk assessment indicated that the hazard quotient (HQ) for ingestion of fluoride laden water exceeded the threshold value in 66.7, 71.4, 52.4 and $9.5 \%$ of the samples for infants, children, teenagers, and adults respectively. It is concluded that groundwater in Makurdi is contaminated with excessive fluoride levels in most locations; hence, the findings of this study would serve as a basis for policy makers and regulatory bodies towards ameliorating the menace of groundwater contamination within the study area.

\section{Highlights}

- Fluoride contamination of groundwater endemic in over $33 \%$ of sample locations

- Moderate positive correlation exist between fluoride and other contaminants

- PCA reveals fluoride contamination of aquifers from dissolution of quartzite and shale

- Groundwater dominated by $\mathrm{Na}-\mathrm{SO}_{4}, \mathrm{Na}-\mathrm{Cl}$ and $\mathrm{Mg}-\mathrm{HCO}_{3}$ water types

- High risk of dental fluorosis in infants, children and teenagers

\section{Introduction}

Fluoride contamination in groundwater has been identified and recognized among the major global environmental pollution concerns (Mahamud, 2012). In addition to nitrates and arsenic, the World Health Organization (WHO) has classified fluoride among the contaminants of drinking water that causes severe health challenges. The WHO has fixed $1.5 \mathrm{mg} / \mathrm{L}$ as tolerable limit for safe drinking of water-containing fluoride (WHO, 2008). This presupposes that intake of fluoride at concentrations higher than the WHO allowable limit, may cause several problems namely dental and skeletal fluorosis, low intelligent quotients in infants, reduced birth rates, neurological disorders and thyroid gland injury (Mohammad et al., 2018). Also, epidemiological research has shown that potable water is the major gateway of fluoride into living organisms.

The elevated levels of fluoride pollution in groundwater have been recorded in various places worldwide. Globally, fluoride contamination in groundwater is prevalent especially in China, India, Kenya, Nigeria, South America (Andes and western Brazil), northwest Iran, Sri-Lanka, and Pakistan (Ali et al. 2016; Dhaya and Shaji, 2017). Continentally, studies have reported elevated fluoride rates in African nations including, Uganda, Tanzania, Sudan, Malawi, Algeria, Kenya, Nigeria, Ghana, Ethiopia and South Africa (Malago et al. 2017).

Particularly in Nigeria, the most affected regions with fluoride contamination are the northern and south-western regions of the country with proportions above WHO discharge limit of $1.5 \mathrm{mg} / \mathrm{L}$ (Akpata et al., 2009). Recently, several researchers have reported high levels of fluoride pollution in groundwater resources in various locations in Nigeria, in which ninety percent of the residents depend on for domestic uses (Malum et al., 2019; Emenike et al., 2018a; Emenike et al., 2018 ; Goyit et al., 2018; Bura et al., 2018; Gwaha, 2017; Olasehinde et al., 2016; Okunola et al., 2016; Dibal et al., 2016; Amadi et al., 2015).

Furthermore, studies have reported moderate to high prevalence rates of fluoride related diseases such as (skeletal and dental fluorosis) in various regions in Nigeria, thus substantiating fluoride contaminations of drinking water in such areas (Idon and Enabulele, 2018; Fulata et al., 2017; Ephraim-Emmanuel et al., 2016; Dirisu et al., 2016). The drinking water which is sourced from groundwater and consumed untreated in most parts of Nigeria has been identified as the main cause of fluoride linked diseases owing to neglected fluoride contamination of such water (Uriah et al., 2014).

In Makurdi metropolis, like many other urban and peri-urban centres in Nigeria, it is impracticable to access treated portable water as a result of poor provision of efficient water treatment systems and lack of stringent water quality standards. This has worsened the situation due to the population explosion in these areas (Emenike et al., 2016: Odjegba et al., 2015; Chia et al., 2014). The available surface water supplies in these areas are either insufficient or are poorly treated and may be contaminated with disease-causing microbial consortiums. Intrinsically, Loading [MathJax]/jax/output/CommonHTML/jax.js peri-urban communities have resulted to the use of borehole water for their domestic needs 
including those for drinking with the specious believe that groundwater is of higher quality (Adekunle et al., 2013). However, following the observed contamination of such groundwater with fluoride and its associated health risk as reported in other climes, it is highly desirable to comprehensively assess the quality of groundwater with regard to fluoride concentrations in Makurdi. This is highly essential in an area like Makurdi where groundwater is the major source of drinking water for the inhabitants. A comprehensive assessment study as intended in the current work will be beneficial to elucidate on the inherent risks to humans in relation to fluoride concentrations of groundwater and also facilitate in decision making in water supplies and regulations.

Recently, scholars have imbibed the Human Health Risk Assessment (HHRA) methodology as well as the use of multivariate statistics to ascertain the relationship existing among the diverse nature and number of water pollutants with a view to identifying the actual source of pollution and the possible mitigation measures to be adopted. Some of these studies cut across areas such as: Iran (Ashrafi et al., 2020; Pazand, 2016), Tunisia (Guissouma et al., 2017), Ghana (Salifu et al., 2012; Ganyaglo et al., 2019), India (Chabukdhara et al., 2017; Ghosh and Mondal, 2018; Ahada and Suthar, 2019) and Ethiopia (Haji et al., 2021) to mention a few. In northern Nigeria, most studies have merely reported elevated fluoride levels in groundwater without a corresponding human health risk analysis and have failed to succinctly identify the likely sources for fluoride contamination of groundwater (Malum et al., 2019; Goyit et al., 2018; Bura et al., 2018; Gwaha, 2017; Olasehinde et al., 2016; Okunola et al., 2016; Dibal et al., 2016; Amadi et al., 2015). In southern Nigeria Emenike et al., (2018) ${ }^{\mathrm{b}}$ and recently, Egbueri and Egbenu (2020) adopted similar approaches to reveal the fluoride levels and associated human health risk in Abeokuta town and Ojoto province respectively. Their findings provided very useful baseline data that could aid practical policy making in water supplies and management in the areas. Thus it is evident that owing to the diverse nature of groundwater pollution across the globe, it is technically pertinent to ascertain the quality of groundwater in every urban or peri-urban environment in order to ascertain the risk associated with the consumption of such water. The adoption of the foregoing inference will assist in preserving the health of the residents of such environments.

Consequently, this study for the first time attempts to extensively assess the quality of groundwater sourced from boreholes in 21 locations in Makurdi metropolis and its environs, North-central, Nigeria during the peak of raining season (October, 2019) with emphasis on its fluoride content and associated human health risk potentials. Firstly, this study seeks to specifically reveal the spatial variations of fluoride and other groundwater quality factors in Makurdi metropolis. Secondly, multivariate statistical approach was employed to uncover the probable sources of fluoride contamination in the water samples as well as establish the interactions that exist among the water pollutants. Finally, the study seeks to adopt the standard risk assessment procedures as recommended by USEPA (2011) to establish the potential human health risk associated with the consumption of fluoride laden groundwater in the study area. The findings of the current study will be beneficial in safeguarding the lives of residents of Makurdi from the adverse consequences of fluoride contamination of groundwater.

\section{Materials And Methods}

Description of the study area

The current study was carried out by sampling groundwater from deep aquifers (boreholes) from 21 locations in Makurdi metropolis of Benue state-Nigeria. The map of Makurdi metropolis and the sampling points is as displayed in Fig. 1, while Table S1 (supplementary material) presents the coordinates of the sampling points.

Makurdi lies between latitude $7.733^{\circ} \mathrm{N}$ and longitude $8.5391^{\circ} \mathrm{E}$ of Greenwich meridian, which is within Southern Guinea Savanna Zone, characterized by distinct wet and dry seasons. The area has experienced a steady rise in urbanization activities in recent times which have also transformed most of its natural endowments. The mean annual rainfall of the area is about 1137mm, falling between April and October (Isikwue and Onyilo, 2010).

The rainfall characteristics classified the patterns into dry season (low amount of rainfall) in November-April and wet season (high amount of rainfall) in May-October. The annual rainfall in Makurdi is estimated by the National Oceanic and Atmospheric Administration to be 1,237 mm (NOAA, 2016), while the period from November to January (hamartan weather) is relatively cool (Isikwue and Oyilo, 2010).

In 2007, Makurdi population was estimated at 500,797 people (The World Gazetteer, 2013). The landform is moderately undulating as revealed by the topographical map of the area. The total annual potential evapotranspiration (PET) is estimated at about 2602 mm, with mean annual relative humidity of about 40.7 percent.

The soil properties of this province are dominated by Makurdi sandstone which is part of the sedimentary basin in Nigeria in the same proportion (Isikwue and Oyilo, 2010) and slightly acidic ( $\mathrm{pH}$ : 4.5-6). The sandstones in this zone are generally fine to medium grained, moderately sorted, micaceous and feldspathic. In some parts, they are calcareous, micaceous and shelly. Various types of cement like iron oxides, silica, dolomites, carbonates and clay were shown to be present in the Makurdi sandstone (lorliam et al. 2013: Akuh, 2014).

Loading [MathJax]/jax/output/CommonHTML/jax.js npling points 
Samples were collected in triplicates in the month of October 2019 from each of the 21 sampling points (P1 - P21), giving a total of 63 samples. In each location the samples were collected from taps connected to borehole supplies usually from an overhead tank. Prior to obtaining samples, the taps were opened and allowed to run onto the ground for about 10 minutes, then samples were collected in freshly purchased $1 \mathrm{~L}$ capacity polyethylene jars.

The freshly purchased polyethylene jars were initially washed with a mixture of distilled water and nitric acid (15\%), rinsed again with distilled water alone and air dried prior to taking them for sampling campaign. At the sampling points the jars were rinsed thrice with the borehole water before obtaining the samples. The collected samples were accurately labeled with the use of masking tapes and marker and immediately conveyed in an ice loaded cooler to the laboratory for tests, while the samples where refrigerated at $4{ }^{\circ} \mathrm{C}$ prior to the test to avoid sample deterioration.

Some of the water quality parameters including $\mathrm{pH}$, Electrical Conductivity (EC) and Total Dissolved Solids (TDS) were determined immediately in the field immediately after the samples were collected. During the field tests, TDS was determined using a TDS meter (HM Digital TDS-4 Pocket Size), pH with a pH meter (Hanna Model HI98107) and EC with a conductivity meter (Suntex model SC-120).

The Nitrate $\left(\mathrm{NO}_{3}^{-}\right)$, bicarbonate $\left(\mathrm{HCO}_{3}^{-}\right)$, chloride $\left(\mathrm{Cl}^{-}\right)$, carbonate $\left(\mathrm{CO}_{3}^{-}\right)$, sulphate $\left(\mathrm{SO}^{2-}{ }_{4}\right)$, sodium $\left(\mathrm{Na}^{+}\right)$, magnesium $\left(\mathrm{Mg}^{2+}\right)$, calcium $\left(\mathrm{Ca}^{2+}\right)$ and potassium $\left(\mathrm{K}^{+}\right)$were measured following standard methods APHA (2005). The fluoride levels was measured potentiometrically using an ion selective electrode (Orion model 25100) coupled to a multimeter (Xplorer GLX model PS-2002), and with the use of a Total lonic Strength Adjustment buffer (TISAB I) in the ratio of 1:1 (ASTM, 1996).

Hydrogeochemical facies and water quality indices

The hydrogeochemical facies of the study location was evaluated using piper diagrams to understand the water type (composition) in terms of the ion (anions and cations) balances. This was performed using Aqua Chem software Version 2014.

The Water Quality Index (WQI) is a recently adopted method for revealing the quality of water at a glance. The WQI computations for each sampling location in the current study involved three successive steps. The first step was 'assigning weight'. Each of the 13 parameters except carbonate was assigned weights (wi), according to its relative importance in the overall drinking water quality. The most significant parameters were given a weight of 5 and the least significant a weight of 3 . In this study, the maximum weight of 5 was assigned for fluoride, TDS, pH, EC, chloride, and nitrate. The sulphate and potassium were assigned weights of 4 , while the less harmful elements, such as sodium, calcium, magnesium and bicarbonate were assigned weights of 3 each. The carbonate was not assigned a weight as it is not regulated by the WHO and was excluded from the computation of WQI.

The second step was the calculation of relative weights for each water quality feature. The relative weight (Wi) was computed using Eq. 1 (Mahmud et al., 2020):

$$
" W_{i}=\frac{w_{i}}{\sum_{i=1}^{n} w_{i}}
$$

Where, $W i$ is the relative weight $w i$ is the weight of each parameter, and $\mathrm{n}$ is the number of parameters.

The third step was the computation of the quality rating scale. The quality rating scale (qi) for each parameter was calculated using Eq. 2.

$$
q_{i}=\frac{C_{i}}{S_{i}} \times 100
$$

2

Where, $q i$ is the quality rating, $\mathrm{Ci}$ is the concentration of each chemical parameter in each water sample in $\mathrm{mg} / \mathrm{L}$, except $\mathrm{pH}$, and $\mathrm{Si}$ is the WHO standard for each chemical parameter and the water quality classification are as presented in Tables S2 and S3 in supplementary material.

Finally, the Wi and qi was used to compute the Sli for each chemical parameter (Eq. 3), and then the WQI is calculated using Eq. 4.

$$
S I_{i}=W_{i} \times q_{i}
$$

Loading [MathJax]/jax/output/CommonHTML/jax.js 


$$
W Q I=\sum_{i=1}^{n} S I_{i}
$$

Where, $S / i$ is the sub-index of each parameter, $q i$ is the rating based on concentration of each parameter, and $\mathrm{n}$ is the number of parameters". The computed WQ/values for each location were categorized following the standard WQI classification scheme as depicted in Table S3, while the detailed computations for the WQI for each location and parameter is detailed in Table S4 (Al - Omran et al., 2015: Ketata-Rokbani et al., 2011).

Human health risk assessment for fluoride contamination

The human health risk assessment is used to account for the nature and probability of antagonistic wellbeing impacts on publics who may be vulnerable to undesirable substances in polluted ecological media, presently or in some other time. Therefore, in this study, the numerical health risk assessment of fluoride via intake of water was assessed in an urban population of Makurdi city, North-central, Nigeria for the first time. In reflection of such interest, water samples collected from boreholes were taken from diverse locations within the city. The population was split into four age categories on the basis of physical and social variances in accordance with the method of Yousefi et al., (2018). Thus, the population was divided as follows: infants ( $<2$ years), children ( 2 to $<6$ years), teenagers ( 6 to $<16$ years) and adults ( $\geq 16$ years). Exposure to fluoride was estimated using Eq. 5.

$$
E D I=\frac{C_{j} \times C_{y}}{B_{X}}
$$

5

Estimated Daily Intake $(E D I)$ of fluoride $\left(\mathrm{mg} / \mathrm{kgB}_{\mathrm{x}} / \mathrm{d}\right)$ was estimated on the basis of the daily mean intake of portable water $\left(\mathrm{C}_{\mathrm{y}}\right)$, amount of fluoride in drinking water $\left(\mathrm{C}_{\mathrm{j}}\right)$ and body weight $\left(\mathrm{B}_{\mathrm{x}}\right)$. The water intake statistics was appraised using questionnaire that were administered on the target populations (infants, children, teenagers, and adults). While data on the average body weight of the various populations (infants, children, teenagers and adults) were computed from data obtained from an epidemiological centre in Makurdi metropolis were most healthy residents are vaccinated from infancy to adulthood. The data collected for this computation was limited within the last five years (20152020) to reflect current realities.

The mean water intake levels in infants, children, teenagers and adults were found to be $0.50,1.0,2.0$ and $2.5 \mathrm{~L} \mathrm{day}^{-1}$ respectively. Average body weights of the target groups were obtained to be 10,18, 45 and $70 \mathrm{~kg}$ for infants, children, teenager and adults respectively.

The non-cancer-causing risk of fluoride to human health was estimated in form of a hazard quotient (HQ) using Eq. 6.

$$
H Q=\frac{E D I}{R f D}
$$

6

The Oral reference Dose (RFD) is an approximation of the day-to-day exposure of the human population to a substance that is not likely to be of any significant harmful risk effects in a lifetime. In this study the RfD for fluoride was taken to be $0.06 \mathrm{mg} / \mathrm{kg} / \mathrm{d}$ (IRISU, 2017; USEPA, 2011). The hazard quotient (which is described as the ratio of EDI to RfD) when obtained to be $<1$ is assumed to be unlikely significant for exposed persons to experience any adverse health effects. However, if the hazard quotient is found to be $>1$, it is an indication of a likely adverse health effect on the exposed population (Yousefi et al., 2018).

Statistical analysis of data

The results of laboratory test were firstly analyzed using descriptive statistics. The extent of violation of the WHO acceptable threshold for each water quality characteristics was also ascertained. Then the Pearson's pair wise correlation was used to elucidate on the relationship between the variables (water quality parameters) at the 0.05 level of significance.

The principal component analysis (PCA) was used to reduce the dimensionality of the water characteristics to facilitate rapid inference of results. PCA was done on the 13 water quality parameters using the Statistical Package for Social Sciences (SPSS) version 21 by the extraction of principal factors using the Varimax orthogonal rotation technique.

Loading [MathJax]/jax/output/CommonHTML/jax.js 
Hierarchical Cluster Analysis (HCA) which is a commonly used approach for grouping a set of interrelated data sets was then applied to the data (both for water quality features and locations). The Ward's method as described in Emenike et al., (2018) ${ }^{\mathrm{b}}$ was adopted for the HCA analysis in the present study using the SPSS statistical software version 21. The hydro-chemical facies of the water samples were elucidated via Piper, Schoeller and Durov diagrams drawn using Aqua Chem (Aq*QA) version 2014 software.

\section{Results And Discussion}

Spatial variations in physico-chemical parameters of Makurdi groundwater

The characteristics of raw groundwater for all 21 locations are presented in Tables S5 and S6 in supplementary material. The descriptive statistics is presented in Table 1. From Table 1, it was observed that majority of the samples were slightly acidic as the pH was noticed to range from 6.2-6.8 across the 21 sampling points as can be seen in Fig. 2, with a mean value of 6.52 . Generally, almost $52.4 \%$ of the samples had $\mathrm{pH}$ levels that fell below the permissible limits for drinking water as stipulated by WHO (WHO, 2017) while the remaining $47.6 \%$ complied with the WHO standard. The slightly acidic nature of the water was which was attributed to the extensive use of fertilizers and pesticides by famers in the water shed of the study locations may impact body metabolism in humans (Chabukdhara et al., 2017).

Table 1

Descriptive Statistics for Physico-Chemical Quality of Water Samples

\begin{tabular}{|llllllll|}
\hline S/No & Parameter & Minimum & Maximum & Mean & SD & WHO Limit & \% Violation \\
\hline 1 & $\mathrm{pH}$ & 6.20 & 6.83 & 6.52 & 0.19 & $6.50-8.50$ & 52.38 \\
\hline 2 & TDS & 89.80 & 1471.50 & 708.02 & 405.09 & 1000 & 28.57 \\
\hline 4 & EC & 158.40 & 2487.40 & 1233.46 & 701.60 & 1500 & 38.10 \\
\hline 5 & Chloride & 38.10 & 532.60 & 165.10 & 110.03 & 200 & 28.57 \\
\hline 6 & Carbonate & 0.00 & 196.00 & 18.70 & 25.52 & - & - \\
\hline 7 & Sicarbonate & 95.00 & 601.00 & 331.56 & 131.85 & 500 & 9.52 \\
\hline 8 & Nitrate & 0.58 & 16.39 & 5.88 & 3.37 & 50 & 71.43 \\
\hline 9 & Fluoride & 0.32 & 2.06 & 1.26 & 0.41 & 1.5 & 0.00 \\
\hline 10 & Sodium & 34.30 & 403.1 & 211.94 & 98.63 & 200 & 33.33 \\
\hline 11 & Potassium & 1.47 & 11.49 & 5.00 & 2.32 & 50 & 57.14 \\
\hline 12 & Calcium & 45.80 & 221.00 & 102.78 & 44.75 & 75 & 0.00 \\
\hline 13 & Magnesium & 28.60 & 237.70 & 90.02 & 48.52 & 150 & 14.29 \\
\hline Note: N & 63, All units are in mg/L with exception of EC ( 14 s/cm) and pH (no unit). SD is Standard Deviation. \\
\hline
\end{tabular}

Total Dissolved Solids (TDS) and Electrical Conductivity (EC) ranged from 89.80-1471.50 mg/L and 158.40-2487.40 $\mu$ s/cm (Fig. 2) with mean values of $708.02 \mathrm{mg} / \mathrm{L}$ and $1233.46 \mu \mathrm{s} / \mathrm{cm}$ respectively. It was found that 28.57 and $38.10 \%$ of the samples violated the WHO limits of $1000 \mathrm{mg} / \mathrm{L}$ and $1500 \mu \mathrm{s} / \mathrm{cm}$ for TDS and EC respectively. Although high concentrations of TDS and EC in drinking water may not be of any severe health implications, such elevated levels can affect the acceptability of such water for drinking purposes as a result of the high scaling effects of such water in household utilities and pipes (WHO 2017).

Additionally, high TDS levels in water can cause gastrointestinal disorders in persons with kidney or renal problems (Chebet et al., 2020). The high levels of TDS and EC in the sampled water can be attributed to the extensive use of fertilizers and pesticides, deep infiltration of rainwater, dissolved sediments and ion exchange (Emenike et al., 2018 ${ }^{\text {; }}$ Egbueri and Mgbenu, 2020). It can also be specifically linked with the dissolution of bicarbonate, sulphate, sodium, calcium and magnesium in the water from natural and anthropogenic processes (Chebet et al., 2020).

Similarly, chloride was found to range from 38.10-532.20 mg/L with average of $165.10 \mathrm{mg} / \mathrm{L}$. Furthermore, about $28.57 \%$ of chloride concentration in the water samples exceeded the WHO limit of $200 \mathrm{mg} / \mathrm{L}$. It should be noted that elevated chloride concentrations in water can induce a salty taste in the water, depending on the associated cation; the salty taste of the chloride anion could be triggered if the Loading [MathJax]/jax/output/CommonHTML/jax.js for sodium, calcium and potassium chloride (WHO 2017). The elevated concentrations of 
chloride in water could be connected with the release of industrial, commercial, and agricultural effluents and runoff (containing de-icing salts) into the environment as well as with the natural solubility of chloride bearing minerals (salts) in water. Similar observations were also reported in the study of Emenike et al., (2018) ${ }^{\mathrm{b}}$ and that of Asuma et al., (2020).

Carbonate and bicarbonate varied from $0.00-196.00 \mathrm{mg} / \mathrm{L}$ and $95.00-601.60 \mathrm{mg} / \mathrm{L}$ with average values of $18.70 \mathrm{mg} / \mathrm{L}$ and $331.56 \mathrm{mg} / \mathrm{L}$ respectively. Although there are no strict regulations for carbonate content of drinking water, it was found that about $9.52 \%$ of the samples exceeded the WHO stipulated limit of $500 \mathrm{mg} / \mathrm{L}$ for bicarbonate in water.

Figure 2 Spatial Variation of Physico-chemical Parameters (a): pH, (b): TDS and EC, (c): Anions and (d): Cations

Activities relating to geological mineralization, irrigation, runoff, and seepage which mix up with groundwater during recharge may be responsible for the heightened levels of bicarbonate in the samples. Similar findings have been reported in previous studies (Akoteyon, 2013; Rasool et al., 2016).

Sulphate concentrations in the samples fell between $39.60-492.10 \mathrm{mg} / \mathrm{L}$ with an average of $283.88 \mathrm{mg} / \mathrm{L}$ which was higher than the WHO acceptable limit ( $250 \mathrm{mg} / \mathrm{L})$ for drinking water. In overview, about $71.4 \%$ violations were noticed from the 21 samples with respect to the WHO stipulated limits (250 mg/L) for sulphate ions in drinking water. Excessive levels of sulphate in water can lead to laxative effects in humans, while moderate levels could induce salty taste in drinking water depending on the associated anions. The foregoing may be responsible for the salty taste of water from deep aquifers within the study area. Furthermore excessively high values of sulphate in drinking water may induce respiratory ailments in humans (Emenike et al., $2018^{\mathrm{b}}$ ). The elevated sulphate concentration is also associated with the excessive use of agro-chemical and dissolution of basement rocks.

Nitrate concentrations in the water sampled was observed to range from $0.58-16.39 \mathrm{mg} / \mathrm{L}$ with a mean concentration of $5.88 \mathrm{mg} / \mathrm{L}$. Nitrate is a strictly regulated compound in drinking water due to its health implications. It causes the blue baby syndrome (methamoglobinemia) in infants and children when present in drinking water at levels higher than $50 \mathrm{mg} / \mathrm{L}$ (Sellami et al., 2019). Despite the excessive use of agrochemicals and fertilizers by farmers in the study area it was observed in this study that none of the samples exceeded the threshold value. Thus, the moderate/low nitrate levels in the groundwater may be linked to the removal of dissolved nitrate by filtration and adsorption activities of the soil profile during seepage and deep percolation (Emenike et al., 2018 ${ }^{\mathrm{b}}$ ).

Fluoride concentration varied from $0.23-2.03 \mathrm{mg} / \mathrm{L}$ with an average concentration of $1.26 \mathrm{mg} / \mathrm{L}$. Most of the water samples complied with the minimum $(0.5 \mathrm{mg} / \mathrm{L})$ and maximum $(1.5 \mathrm{mg} / \mathrm{L})$ threshold values for fluoride in drinking water (WHO 2017). Succinctly, about one-third $(33.33 \%)$ of samples were found to exceed the maximum permissible limits, while only one of the samples had fluoride concentrations lower than the minimum acceptable limit $(0.5 \mathrm{mg} / \mathrm{L})$. High fluoride levels in water samples can be linked to the fluoride bearing rocks found in the geological formations, and myriad of anthropogenic activities in the study area. Fluoride concentration in water above $1.5 \mathrm{mg} / \mathrm{L}$ is reported to be responsible for dental fluorosis in humans (especially children), while excessive concentrations are reported to cause skeletal fluorosis in children and adults (WHO, 2004). It is usually referred to as the double edge sword as low intakes of fluoride in humans can also cause dental caries (Yousefi et al., 2018). Based on the reports from recent studies, it is presumed that excessive intake of fluoride can be carcinogenic in humans (WHO, 2004). Thus, fluoride removal from drinking water supplies is highly essential in the provision of potable drinking water. Sodium concentrations in the samples ranged from 34.30-403.1 mg/L (with mean value of $211.94 \pm 98.63 \mathrm{mg} / \mathrm{L}$ ). There was an evident high variability in the sodium content of the water with about $57.14 \%$ of the samples surpassing the WHO limits of $200 \mathrm{mg} / \mathrm{L}$. The high sodium level in the water was attributed to aquifer chemistry and the mixing of wastewater effluent (generated through human activities) with the groundwater in the study locations (Tirkey et al., 2017).

Potassium, calcium and magnesium concentrations in the water samples were found to range from 1.47-11.49 mg/L, 45.80-221.00 mg/L and $28.60-237.70 \mathrm{mg} / \mathrm{L}$ respectively. Potassium concentrations in the samples were found to fully comply (100\%) with the WHO limits. Since $\mathrm{Mg}^{+}$and $\mathrm{Ca}^{+}$are major pointers to water hardness. In the current study, $\mathrm{Ca}^{+}$values were within the WHO permissible limit (200 mg/L) for all

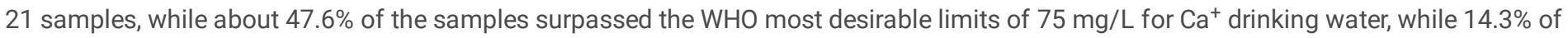
the samples had $\mathrm{Mg}^{+}$concentrations above the WHO permissible limit ( $150 \mathrm{mg} / \mathrm{L}$ ) and over $90 \%$ of the samples had values higher than the most desirable limits of $50 \mathrm{mg} / \mathrm{L}$. It was inferred therefore, those groundwater in the study locations were generally hard and tasty. High levels of these cations in the water samples were traced to mineral dissolution in the basement and ion exchange activities (Magesh et al., 2017).

Water quality assessment

The quality of water samples was assessed through the Water Quality Index (WQI) and water type (hydrogeochemical facies) using piper diagram consisting of composite-double triangles and a diamond shape. Each of the triangles represents either the cation or anion comnncition of the water samnles while the diamond shape is a composite plot for both the cations and anions. Loading [MathJax]/jax/output/CommonHTML/jax.js 
For the WQI, weights and relative weights were assigned to the water quality parameters as depicted in the supplementary material (Table S1). The data in Table S3 is the computations of the WQI and remarks for all the studied locations and the results are presented in Fig. 3. It was observed that about 95\% of the samples fell into class II (good water), see Table S2, while one sample (P14) had quality that fell into class I of the WQI classification, which suggest that the water is clean and safe. Furthermore, it was noticed that the major contributors to the overall WQI in the study locations were in the order of sulphate $>$ EC $>$ Chloride $>$ Calcium $>$ Fluoride $>$ TDS $>$ pH $>$ Sodium. Magnesium and bicarbonate were observed to have moderate contributions to the water quality, while nitrate and potassium had the least contributions. The findings of this study are in tandem with that of Adimalla et al., (2018).

Figure 3 Water Quality Index (WQI) for the Studied Locations

Although most of the samples were found to be good for drinking, the threshold values obtained for most locations (P1, P2, P4, P6, P8, P13) were observed to be very close to been ranked as class III water type ("poor water"). Thus, it is suggested that simple technologies such as filtration and adsorption could be deployed as treatment techniques for water in the affected locations to eliminate the major contributing pollutants such as sulphate, chloride, fluoride, calcium sodium, among others). In light of this, the affected water may be safer for human consumption.

Furthermore, the piper diagram (Figure S1) shows that the $\mathrm{Na}^{+}, \mathrm{Ca}^{2+}$ and $\mathrm{Mg}^{2+}$ are the major cations with $\mathrm{Ca}^{2+}$ and $\mathrm{Na}^{+}$dominating, while $\mathrm{K}^{+}$ was found to have a moderate contribution to the general description as indicated the in WQI computations. In the anions sections, $\mathrm{SO}_{4}{ }^{2-}$ and $\mathrm{Cl}^{-}$were observed to dominate the facies, while contributions from $\mathrm{HCO}_{3}$ was found to be moderate. The dominance of $\mathrm{Ca}^{2+}$ and $\mathrm{Na}^{+}$in the water composition is an indicator of the possibility of ion exchange through rock weathering in the aquifer. The dominance of $\mathrm{SO}_{4}{ }^{2-}$ and $\mathrm{Cl}^{-}$ on the other hand reveal ion contributions as a result of silica weathering (Achary et al., 2016).

Additionally, Aghazadeh, et al., (2016) posited that when the ratio of calcium/magnesium ions in water is between 0.6 and a value higher than 2 , it is a pointer to the possible dissolution of dolomite and silicate rock constituents in the aquifer. In the current study, more than $80 \%$ of the samples had calcium/magnesium ratios that fell between 0.6 and 3.4 confirming the interaction of silicate and dolomite materials in the aquifer. The overall characterization of the hydrogeochemical facies revealed the dominance of $\mathrm{Na}-\mathrm{SO}_{4}(42.8 \%), \mathrm{Na}-\mathrm{Cl}(14.30 \%), \mathrm{Mg}^{-} \mathrm{HCO} \mathrm{C}_{3}$ (14.30\%), $\mathrm{Mg}_{-} \mathrm{SO}_{4}(9.5 \%), \mathrm{Ca}-\mathrm{HCO}_{3}(4.8 \%), \mathrm{Mg}-\mathrm{Cl}(4.8 \%), \mathrm{Ca}-\mathrm{Cl}(4.5 \%)$ and mixed water types (5 \%) in the studied locations (Fig. 4$)$. The foregoing is indicative of the predominant salty taste of bore-hole water in the study area. Additional information on the hydro-chemical characterization of the water samples in form of the Durov and Schoeller diagrams can also be found in supplementary material (Figures S2 and S3).

Multivariate statistical analysis and pollution source apportionment

In the current study, Pearson's correlation, principal component, and hierarchical cluster analyses were adopted to further corroborate the relationship and likely sources of contaminants in groundwater of the study area. These techniques have been utilized in several studies on the water quality assessment (Emenike et al., 2018b; Ali and Ali, 2018; Ravikumar and Somashekar, 2017; Rassol et al., 2016; Salifu et al., 2012). For correlation analysis (CA) when $r$ values less than 0.3 the association was taken as weak correlation, when it varied between $0.3-$ 0.7 , the relationship is regarded as being moderate and when $r$ was greater than 0.7 the relationship is considered as strong (Emenike et al., $2018^{\text {b. }}$ Salifu et al., 2012).

\section{Correlation analysis}

The results of correlation analysis (CA) are presented in Table 2. With regards to the relationship between fluoride and other ions in the water samples, it was found that fluoride was moderately and positively correlated with TDS, $\mathrm{EC} \mathrm{Cl}^{-}$and $\mathrm{NO}_{3}{ }^{-}$. This suggests that these parameters have similar sources with fluoride, which occurs from rock weathering and geological interactions. For instance, Bempah, (2014) reported similar relationship between fluoride, TDS and EC in his study on arsenic contamination of groundwater in Ghana.

Loading [MathJax]/jax/output/CommonHTML/jax.js 
Table 2

Correlation Analysis for Water Quality Parameters

\begin{tabular}{|c|c|c|c|c|c|c|c|c|c|c|c|c|c|}
\hline & $\mathrm{pH}$ & TDS & EC & $\mathrm{Cl}^{-}$ & $\mathrm{CO}_{3}{ }^{2-}$ & $\mathrm{HCO}_{3}{ }^{-}$ & $\mathrm{SO}_{4}{ }^{2-}$ & $\mathrm{NO}_{3}{ }^{-}$ & $\mathrm{F}^{-}$ & $\mathrm{Na}^{+}$ & $\mathrm{K}^{+}$ & $\mathrm{Ca}^{2+}$ & $\mathrm{Mg}^{2+}$ \\
\hline $\mathrm{pH}$ & 1 & & & & & & & & & & & & \\
\hline TDS & 0.229 & 1 & & & & & & & & & & & \\
\hline EC & 0.235 & $0.980^{* *}$ & 1 & & & & & & & & & & \\
\hline $\mathrm{Cl}^{-}$ & -0.133 & 0.162 & 0.159 & 1 & & & & & & & & & \\
\hline $\mathrm{CO}_{3}{ }^{2-}$ & -0.130 & $0.326^{* *}$ & $0.324^{\star \star}$ & $0.378^{\star \star}$ & 1 & & & & & & & & \\
\hline $\mathrm{HCO}_{3}{ }^{-}$ & -0.196 & $0.290^{\star}$ & $0.338^{\star \star}$ & 0.012 & 0.205 & 1 & & & & & & & \\
\hline $\mathrm{SO}_{4}{ }^{2-}$ & 0.197 & 0.113 & 0.158 & 0.094 & -0.023 & 0.142 & 1 & & & & & & \\
\hline $\mathrm{NO}_{3}{ }^{-}$ & 0.131 & -0.134 & -0.076 & 0.147 & -0.241 & $-0.322^{\star *}$ & 0.117 & 1 & & & & & \\
\hline $\mathrm{F}^{-}$ & 0.004 & $0.472^{* *}$ & $0.484^{* \star}$ & $0.457^{\star \star}$ & 0.142 & -0.085 & 0.087 & $0.279^{*}$ & 1 & & & & \\
\hline $\mathrm{Na}^{+}$ & 0.105 & 0.184 & 0.223 & -0.017 & -0.108 & 0.176 & $0.869^{* \star}$ & 0.176 & 0.068 & 1 & & & \\
\hline $\mathrm{K}^{+}$ & 0.011 & $0.341^{\star *}$ & $0.361^{\star *}$ & 0.067 & -0.004 & 0.177 & $0.756^{* *}$ & 0.122 & 0.239 & $0.805^{\star \star}$ & 1 & & \\
\hline $\mathrm{Ca}^{2+}$ & 0.148 & -0.074 & -0.071 & -0.099 & -0.218 & -0.179 & $0.499^{* *}$ & 0.156 & -0.117 & $0.512^{* \star}$ & $0.540^{* \star}$ & 1 & \\
\hline $\mathrm{Mg}^{2+}$ & 0.039 & 0.200 & $0.252^{*}$ & $0.352^{\star *}$ & 0.129 & $0.295^{*}$ & $0.374^{* *}$ & -0.040 & 0.018 & $0.259^{*}$ & $0.285^{*}$ & 0.070 & 1 \\
\hline
\end{tabular}

Similarly, $\mathrm{F}^{-}$was observed to be positively and weakly correlated with $\mathrm{SO}_{4}{ }^{2-}, \mathrm{CO}_{3}{ }^{-} \mathrm{pH}$ and all the cations except $\mathrm{Ca}^{2+}$. This indicates that the sources of these contaminants in the water are probably from geological interactions. It was however observed that $\mathrm{F}^{-}$had a negative and weak correlation with $\mathrm{HCO}_{3}{ }^{-}$and $\mathrm{Ca}^{2+}$, signifying that the trio are likely from different sources $\mathrm{HCO}_{3}{ }^{-}$, and $\mathrm{Ca}^{2+}$ from anthropogenic and $\mathrm{F}^{-}$ from natural sources). Similar observations were reported by Emenike et al., (2018 ${ }^{b}$ ) in addition to that of Adimilla and Venkatayogi, (2017).

Also, strong positive correlations were observed for $\mathrm{EC}$ - TDS, $\mathrm{Na}^{+}-\mathrm{SO}_{4}{ }^{2-}, \mathrm{K}^{+}-\mathrm{SO}_{4}{ }^{2-}$ and $\mathrm{Na}^{+}-\mathrm{K}^{+}$, while moderate positive correlations were noticed for $\mathrm{CO}_{3}{ }^{-}-\mathrm{TDS}, \mathrm{K}^{+}-\mathrm{TDS}, \mathrm{CO}_{3}{ }^{-}-\mathrm{EC}, \mathrm{HCO}_{3}{ }^{-}-\mathrm{EC}, \mathrm{K}^{+}-\mathrm{EC}, \mathrm{CO}_{3}{ }^{-}-\mathrm{Cl}^{-}, \mathrm{Mg}^{2+}-\mathrm{Cl}^{-}, \mathrm{NO}_{3}{ }^{-}-\mathrm{HCO}_{3}{ }^{-}, \mathrm{Ca}^{2+}-\mathrm{SO}_{4}{ }^{2-}, \mathrm{Mg}^{2+}-\mathrm{SO}_{4}{ }^{2-}, \mathrm{Ca}^{2+}-\mathrm{Na}^{+}$and $\mathrm{Ca}^{2+}-\mathrm{K}^{+}$(Table 2), thus indicating source similarities of the parameters. No negatively strong or moderate correlations were observed, however, most of the parameter $\left(\mathrm{pH}-\mathrm{Cl}^{-}, \mathrm{pH}-\mathrm{CO}_{3}{ }^{-}, \mathrm{pH}-\mathrm{HCO}_{3}{ }^{-}, \mathrm{NO}_{3}{ }^{-}-\mathrm{Mg}^{2+}\right.$ among others) exhibited a weak negative relationship suggesting that these input into the water samples from different routes (Table 2).

Comparatively, fluoride concentrations in the current study were observed to be higher than the mean values reported from other studies

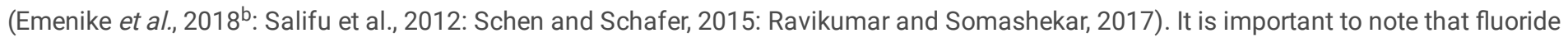
content in groundwater tends to increase as the TDS and EC values increases (Rafique et al., 2009). This trend was also observed in the current study. Although fluoride was found to be weakly correlated with $\mathrm{pH}$ in this study, the findings support the assertion that fluoride solubility is $\mathrm{pH}$ dependent (fluoride solubility in water is favoured when the $\mathrm{pH}$ ranges from 6-9).

The $\mathrm{pH}$ of the samples were found to range between $6.2-6.83$ in the current study with an average of 6.52 which is likely responsible for the high fluoride values recorded (Saxena and Ahmed, 2001). Furthermore, the presence of fluoride in the water samples could be linked to the dissolutions from quartzite and shale (which are the major geological sediments of the study locations) into the underlying aquifer (Eneji et al., 2011).

\section{Principal component analysis (PCA)}

In this study, PCA revealed four principal components (PC) with a cumulative variance of $71.53 \%$ (rotation sum of squared loadings) as illustrated in Table 3 and the scree plot (Figure S4). It was observed from Figure S4 that about 13 factors were extracted in total but only four of them were seen to have Eigen values greater than 1 and they were considered as the principal components (PC). PC1 had strong and Loading [MathJax]/jax/output/CommonHTML/jax.js $]$, calcium, potassium, and magnesium with an explicated variance of $24.7 \%$ (Table 3 ). This also 
indicates the contribution of rock weathering and ion exchange activities in the hydro-geo-chemistry of the studied aquifers, which also implies that the cations originate from similar geogenic sources (dolomite and gypsum).

Table 3

Varimax Rotated Principal Component Analysis for the Water Samples

\begin{tabular}{|lllll|}
\hline \multirow{2}{*}{ Parameter } & \multicolumn{4}{l}{ Rotated Component Matrix } \\
\cline { 2 - 5 } & PC1 & PC2 & PC3 & PC4 \\
\hline pH & 0.109 & 0.428 & -0.509 & 0.251 \\
\hline Total Dissolved Solids & 0.097 & $\mathbf{0 . 9 4 5}$ & 0.085 & -0.176 \\
\hline Electrical Conductivity & 0.140 & $\mathbf{0 . 9 4 3}$ & 0.107 & -0.174 \\
\hline Chloride & 0.005 & 0.135 & $\mathbf{0 . 8 4 7}$ & 0.242 \\
\hline Carbonate & -0.154 & 0.293 & $\mathbf{0 . 5 3 3}$ & -0.309 \\
\hline Bicarbonate & 0.157 & 0.179 & 0.206 & -0.744 \\
\hline Sulphate & $\mathbf{0 . 9 1 3}$ & 0.067 & 0.068 & -0.001 \\
\hline Nitrate & 0.182 & -0.025 & 0.076 & $\mathbf{0 . 7 7 3}$ \\
\hline Fluoride & 0.010 & $\mathbf{0 . 5 8 5}$ & $\mathbf{0 . 4 2 8}$ & $\mathbf{0 . 4 6 6}$ \\
\hline Sodium & $\mathbf{0 . 9 2 1}$ & 0.108 & -0.054 & -0.021 \\
\hline Potassium & $\mathbf{0 . 8 6 9}$ & 0.244 & 0.095 & -0.006 \\
\hline Calcium & $\mathbf{0 . 6 9 6}$ & -0.148 & -0.236 & 0.197 \\
\hline Magnesium & $\mathbf{0 . 4 0 7}$ & 0.092 & $\mathbf{0 . 4 5 1}$ & -0.253 \\
\hline \% of Variance & 24.69 & 19.62 & 13.74 & 13.47 \\
\hline Cummulative \% & 24.69 & 44.32 & 58.06 & 71.53 \\
\hline * Bolded indices show heightened & positive loadings & \\
\hline
\end{tabular}

PC2 was observed to have strong positive loadings for $\mathrm{pH}, \mathrm{TDS}, \mathrm{EC}$, and fluoride with a total explainable variance of $19.6 \%$. This indicate that the occurrence of these contaminants in water owing to similar natural and/or anthropogenic activities, probably from the solubilization of halite and high evapotranspiration rates. It also implies the role of $\mathrm{pH}$ in the dissolution and mobility of anions (especially fluoride) and cations in water, as the solubility of fluoride in water is favoured in the pH range of 6-9 as earlier stated (Saxena and Ahmed, 2001), since both TDS and EC values are major indicators of ion concentrations in water.

PC2 also confirms the positive correlation of TDS and EC with fluoride in water and further substantiate the assertion that fluoride concentrations in water tends to increase with upsurge in TDS and EC (Rafique et al., 2009). The component plot in rotated space illustrates the factor loadings for the principal components as shown in Figure S5. PC3 and PC4 were found to have negligible contributions to the water chemistry as they had strong positive factor loadings for chloride, carbonate, nitrate, fluoride, and magnesium with explainable variance of 13.74 and $13.47 \%$ respectively.

The dominance of carbonate in PC3 indicates its contribution in the dissolution and distribution of fluoride and nitrate in groundwater. It was also observed that fluoride and magnesium exhibited a quasi-independent behaviour in PC1, PC2, PC3 and PC 4, which implies that they are introduced into the water from majorly from natural (geogenic) and on a minor note through anthropogenic sources (Hosseini et al., 2019).

\section{Hierarchical cluster analysis (HCA)}

The HCA were performed in this study using the Ward's method by selecting the squared Euclidean distance as the interval and the hydrochemical results of all samples were statistically analyzed. The data used was normalized before the analysis. The HCA was performed in the Variable and Case-modes, such that the Variable-mode provided the relationships between water quality parameters, while the Case-mode revealed the relationships between the sample locations (Sharaf and Subyani, 2011: Bempah, 2014).

The HCA was performed for the set of water samples from 21 locations with three replications each (giving rise to 63 cases) and 13 water Loading [MathJax]/jax/output/CommonHTML/jax.js $\mathrm{HCA}$ in form of a dendrogram for the Variable-mode is shown in Figure S6, while that for the 
Case-mode is depicted in Figure S7. It was observed that the variables were grouped into two clusters. The parameters were observed to be grouped on account of their concentrations in the water samples. The $\mathrm{pH}, \mathrm{K}^{+}, \mathrm{NO}_{3}{ }^{-}, \mathrm{F}^{-}, \mathrm{CO}_{3}{ }^{-}, \mathrm{Ca}^{2+}, \mathrm{Mg}^{2+}, \mathrm{Cl}^{-}, \mathrm{SO}_{4}{ }^{2-}, \mathrm{Na}^{+}$and $\mathrm{HCO}_{3}{ }^{-} \mathrm{were}^{-}$ grouped in the same cluster (cluster 1), while TDS and EC formed the second cluster. Despite TDS and EC having relatively higher linkage as compared to the other variable, they were found to be closely related owing to their strong positive correlations with most of the studied parameters (Bempah, 2014).

Furthermore, $\mathrm{Na}^{+}, \mathrm{SO}_{4}{ }^{2}, \mathrm{HCO}_{3}{ }^{-}$were observed to be closely connected which indicate the impact of rock weathering and ion exchange activities on the water chemistry as earlier shown in the correlation and PCA together with the dominance of $\mathrm{Na}-\mathrm{SO}_{4}$ and $\mathrm{Na}^{-} \mathrm{HCO} \mathrm{C}_{3}$ water types in the hydrogeochemical facies of the studied locations. The $\mathrm{pH}, \mathrm{Cl}^{-}, \mathrm{CO}_{3}{ }^{-}, \mathrm{NO}_{3}{ }^{-}, \mathrm{F}^{-}, \mathrm{K}^{+}, \mathrm{Ca}^{2+}, \mathrm{Mg}^{2+}$ were also found to be closely clustered suggesting source similarities and the involvement of $\mathrm{pH}$ in the mobility and speciation of the ions in groundwater.

On the other hand, it was observed that the sample locations were grouped into four clusters on the basis of the similarities in the water chemistry of the locations. Locations P1, P2, P3, P4, P5, P6, P8, P10, P12 and P18 were grouped into clusters 1 and 2, while locations P7, P9, P11, P13, P14, P15, P16, P17, P19, P20 and P21 were grouped into clusters 3 and 4. The implications of the groupings may be linked to the close proximity of the sample locations as earlier stated in the coordinate locations. In general, there was no significant distinctions in the water quality of the studied locations as the samples were observed to have similar characteristics in terms of its quality.

Human health risk analysis for fluoride contamination of groundwater

Despite the seemingly good quality of the groundwater for drinking purposes as demonstrated in the results of the WQI analysis, it is essential to evaluate the potential health risk of the exposed populations to fluoride contamination. This is apparent as some fractions of the samples were observed to contain fluoride concentrations that exceeded the allowable limits for drinking water in order to prevent fluorosis in humans.

The results of the estimated daily fluoride intake for each location is presented in Figure S8, while that for the hazard quotient per location for every human category is shown in Fig. 4. Figure S8 represents the exposure levels of the populations (infants, children, teenagers and adults) to fluoride risk, while Fig. 4 depicts the hazard quotient (an indicator of actual risk) for risk of fluorosis in the vulnerable population. Details of the computations for the risk assessment are available as supplementary material (Table S7).

From Figure S8, it was observed that the EDI Values were considerably high in most of the locations especially in infants and children. A moderate level of EDI was observed in most locations for teenagers, while adults in all locations except one (P13) were found to have EDI levels for fluoride that were lower than the RfD value of $0.06 \mathrm{mg} / \mathrm{kg} / \mathrm{d}$. Generally, EDI values ranged from $0.023-0.100,0.025-0.110,0.020-$ 0.088 and $0.016-0.071 \mathrm{mg} / \mathrm{kg} / \mathrm{d}$ for infants, children, teenagers and adults respectively. Among the studied cases locations, P14 and P13 had the lowest and highest EDI values respectively, which follow after the mean fluoride concentrations of these locations.

From the computations of the hazard quotient (HQ) (Fig. 4), it was noticed that for infants, about $66.7 \%$ of the sample locations had HQ values in excess of the set limit (1). This implies that this population is vulnerable to high risk of fluoride related disorders due to ingestion of fluoride laden groundwater. Similarly, with respect to children, teenagers and adults, it was observed that about $71.4,52.4$ and $9.5 \%$ of the sample locations were at elevated risk of developing fluoride related diseases from the consumption of high-fluoride content water.

Figure 4 Hazard Quotient for Fluoride Risk in the studied Populations

It is evident that children had the highest potential risks for developing fluorosis even higher than that for infants, since the ratio of the daily water intake rates and body weight for the children is considerably higher than that for the infants. Moreover, this is expected as the children undergo more metabolic activities as a result of mobility and play which demands for more water consumption as compared to the infants. As for the teenagers and adults, the risk as earlier stated could be moderate and low respectively. This could be attributable to the ratio of the daily water intake rates and body weight, coupled with the associated metabolisms. As expected, teenagers are more prone to high metabolic rates and thus higher water intake rates irrespective of their moderate body weight.

Despite the moderate and low risk levels for teenagers and adults respectively when considering the entire study location, it is pertinent to note that locations P13 and P19 had very high risk levels for all age categories and therefore, this study recommend that groundwater from these locations should be subjected to affordable defluoridation systems prior to consumption. Several studies have reported analogous risk

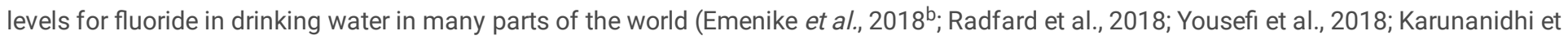
al., 2019; Nakazawa et al., 2020).

\section{Conclusions}

Loading [MathJax]/jax/output/CommonHTML/jax.js 
This study successfully assessed groundwater in Makurdi metropolis with emphasis on its fluoride content and associated human health risk. The findings from this study shows that significant variation in the physico-chemical parameters across the sampling points considered exist. It was observed that fluoride content of the water exceeded the WHO limit of $1.5 \mathrm{mg} / \mathrm{L}$ in $33.3 \%$ of the various sampling locations. The multivariate statistical data shows that the source of groundwater contamination was largely from geogenic activities majorly from the dissolution of quartzite, dolomite and shale into the deep aquifers of Makurdi and its environs, while human health risk assessment for fluoride contamination of the groundwater revealed that, 66.7, 71.4, 52.4 and $9.5 \%$ of the population in the sampling locations for infants, children, teenagers and adults respectively are at high risk of developing fluoride related disorders from the consumption of fluoride laden water. Moreover, multivariate statistics was successful in describing the relationships that exist among the diverse nature of pollutants in groundwater and was able to establish the source of pollutants in the studied groundwater samples. Water quality index analysis revealed that aside the elevated fluoride levels in some of the samples the water was largely suitable for domestic use based on the parameters considered in this study.

The results of this study (first of its kind) will serve as baseline data and provide information on the quality status of groundwater obtained from boreholes in Makurdi town and its environs with specific emphasis on fluoride pollution levels and its associated adverse health effects. Thus, this study proposes that groundwater sources in the study area at the household scales should be subjected to affordable and efficient water treatment technologies such as batch adsorption or cloth filtration prior to consumption for the containment of fluoride and related contaminants.

Finally, future studies should be undertaken in the studied location for samples obtained from groundwater in the dry spell (November March) and the results should be compared to those reported in the current study. This will ascertain if significant temporal or seasonal variations in the groundwater quality exist or any prevailing changes in the fluoride risk potentials, and further guide policy decisions in water supply and management in the study area. Other emerging pollutants of concern should be considered and studied using similar or different approach.

\section{Declarations}

Funding: The authors did not receive support from any organization for the submitted work

Conflict of interest/Competing interests: The authors have no conflicts of interest to declare that are relevant to the content of this article.

Availability of data and material: Data for this work are included in the supplementary material

Code availability: Not applicable

Authors' contribution: Raphael T. Iwar conceived the research, designed and conducted the experiments and wrote the first draft of the manuscript. Kola' Ogendengbe supervised the work, technically edited the manuscript and validated the data. Kamil K. Katibi participated in data collection, visualization and analysis and writing of first draft. Josiah N. Jabbo contributed in data curation, visualization and analysis and technically edited the manuscript. All authors read the final edited manuscript and approved it for publication.

\section{References}

1. Achary, M. S., Panigrahi, S., Satpathy, K. K., Prabhu, R. K., \& Panigrahy, R. C. (2016). Health risk assessment and seasonal distribution of dissolved trace metals in surface waters of Kalpakkam, southwest coast of Bay of Bengal. Reg. Stud. Mar. Sci., 6, 96-108. https://doi.org/10.1016/j.rsma.2016.03.017.

2. Adekunle, A. A., Adedayo, O. B., \& Abiola, O. O. (20130. Pollution studies on groundwater contamination: Water quality of Abeokuta, Ogun state, South-West Nigeria. Journal of Environ. Earth Sci. 3, 161-166.

3. Adimalla, N., \& Venkatayogi, S. (2017). Mechanism of fluoride enrichment in groundwater of hard rock aquifers in Medak, Telangana State, South India. Environ. Earth Sci. 76,45. https://doi. org/10.1007/s12665-016-6362-2.

4. Adimalla, N., Li, P., \& Venkatayogi, S. (2018). Hydrogeochemical evaluation of groundwater quality for drinking and irrigation purposes and integrated interpretation with water quality index studies. Environ. Proc. 5,363-83.

5. Ahada, C. P. S., \& Suthar, S. (2019). ). Assessment of Human Health Risk Associated with High Groundwater Fluoride Intake in Southern Districts of Punjab, India. Expos, \& Healt. 11, 267-275. https://doi.org/10.1007/s12403-017-0268-4. (.

6. Aghazadeh, N., Chitsazan, M., \& Golestan, Y. (2016). Hydrochemistry and quality assessment of groundwater in the Ardabil area, Iran. Appl. Water Sci., 7(7), 3599-3616. https://doi.org/10.1007/s13201-016-0498-9.

Loading [MathJax]/jax/output/CommonHTML/jax.js 
7. Akpata, E. S., Danifillo, I. S., Otoh, E. C., \& Mafeni, J. O. (2009). Geographical mapping of fluoride levels in drinking water sources in Nigeria. Afric. Health Sci., 9(4), 227-233.

8. Akuh, T. I. (2014). Hydrogeology and groundwater quality in Makurdi metropolis and its environs, part of Makurdi (sheet 251), North Central Nigeria. MSc. Thesis Department of Geology, Faculty of Science, Amhadu Bello University, Zaria, Nigeria, 151pp.

9. Ali, S. A., \& Ali, U. (2018). Hydrochemical characteristics and spatial analysis of groundwater quality in parts of Bundelkhand Massif, India. Appl. Water Sci, 8, 39.

10. Ali, S., Thakur, S. K., Sarker, A., \& Shekhar, S. (2016). Worldwide contamination of water by fluoride. Environ. Chem. Let. DOl: 10.1007/s10311-016-0563-5.

11. Amadi, A.,N., Tukur, A., Okunola, I. A., Olasehinde, P. I., \& Jimoh, M. O. (2015). Lithologic influence on the hydrogeochemical characteristics of groundwater in Zango, North-west Nigeria. Nat. Resour. \& Conser, 3(1), 11-18.

12. Al-Omran, A., Al-Barakah, F., Altuquq, A., Aly, A., \& Nadeem, M. (2015). Drinking water quality assessment and water quality index of Riyadh, Saudi Arabia. Water Quality Research Journal of Canada, 50(3), 287-296.

13. APHA. (2005). Standard Methods for the Examination of Water and Wastewater, twentieth ed. USA: American Public Health Association, Baltimore, Maryland.

14. Ashrafi, S. D., Jaafari, J., Sattari, L., Esmaeilzadeh, N., \& Safari, G. H. (2020). Monitoring and health risk assessment of fluoride in drinking water of East Azerbaijan Province, Iran. International Journal of Environmental Analytical Chemistry. https://doi.org/10.1080/03067319.2020.1849662.

15. ASTM Method D9214 (1996). Potentiometric determination of fluoride in aqueous samples with ion selective electrodes, USA.

16. Asuma, O.O., Emekeme, R.I., Aweto, K.E., Ofomola, M.V. (2020). Geophysical investigation of resistivity and groundwater quality in Ogbehljoh coastal area of Western Niger-Delta of Nigeria. Appl. Water Sci. 10,70. https://doi.org/10.1007/s13201-020-1144-0.

17. Bempah, C. K. (2014). Arsenic Contamination of Groundwater in South Western Part of Ashanti Region of Ghana. PhD Thesis, Faculty of Environmental Sciences and Process Engineering, Brandenburg University of Technology, Cottbus-Senftenberg, Germany.

18. Bura, B., Goni, I.B., Sherrif, B.M. and Gazali, A.K. (2018). Occurrence and distribution of fluoride in groundwater of chad formation aquifers in Borno State, Nigeria. International J. Hydro. 2(4), 528-537.

19. Chabukdhara, M., Gupta, S. K., Kotecha, Y., \& Nema, A. K. 2017. Groundwater quality in Ghaziabad district, Uttar Pradesh, India: Multivariate and health risk assessment. Chemos.179, 167-178.

20. Chebet, E. B., Kibet, J. K., \& Mbui, D. (2020). The assessment of water quality in River Molo water basin, Kenya. Appl. Water Sci. $10,92$. https://doi.org/10.1007/s13201-020-1173-8.

21. Chia, V. D., Ijir, S. T., Iwar, R., \& Ndulue, E. L. (2014). The contending issues of domestic water supply in Makurdi metropolis, Benue State, Nigeria. Civil \& Environ. Res., 6(9), 89-96.

22. Dhanya, R., \& Shaji, I. (2017). Fluoride contamination in groundwater resources of Alleppey, Southern India. Geosci. Front. 8(1), 117-124..

23. Dibal, H. U., Schoeneich, K., Lar, U. A., Garba, I., Lekmang, I. K., \& Daspan, R. I. (2016). Hydrogeochemical appraisal of fluoride in groundwater of Langtang area, Plateau State, Nigeria. Global J. Geo. Sci. 14, 23-39. DOI: http://dx.doi.org/10.4314/gjgs.v14i1.3.

24. Dirisu, C. G., Mafiana, M. O., Okwodu, N. E., \& Isaac, A. U. (2016). Fluoride content of community Drinking Water: Biological and public health implications. American J. Water Resour., 4(3), 54-57.

25. Egbueri, J. C., \& Mgbenu, C. N. (2020). Chemometric analysis for pollution source identification and human health risk assessment of water resources in Ojoto Province, southeast Nigeria. Appl. Water Sci., 10, 98. https://doi.org/10.1007/s13201-020-01180-9.

26. Emenike, P. C., Nnaji, C. C., \& Tenebe, I. T. (2018)a . Assessment of geo-spatial and hydro- chemical interactions of groundwater quality, Southern Nigeria. Environ. Monit. \& Assess. 2018, 190-440. DOI: doi.org./10.1007/s10661-018-6799-8.

27. Emenike, P. C., Tenebe, I. T., \& Jarvis, P. (2018) ${ }^{\text {b }}$. Fluoride contamination in groundwater sources in Southwestern Nigeria: Assessment using multivariate statistical approach and human health risk. Ecotox. \& Environ. Safety, 156, 391-402. https://doi.org/10.1016/j.ecoenv.2018.03.022.

28. Emenike, P. C., Omole, D. O., Ngene, B. U., \& Tenebe, I. T. (2016). Potentiality of agricultural adsorbent for the sequestering of metal ions from wastewater. Glob. J. Environ. Sci. Manage., 2, 411-442. https://doi.org/10.22034/gjesm.2016.02.04.010.

29. Eneji, I. S., Sha'Ato, R., \& Annune, P. (2011). An assessment of heavy metals loading in River Benue in the Makurdi Metropolitan Area in Central Nigeria. Environ. Monit. \& Assess., 184(1), 201-207. DOI:10.1007/s10661-011-1959-0.

30. Ephraim-Emmanuel, B. C., Abara, A. A., Ogbomade, R., \& Francis, E. (2016). Prevalence of dental fluorosis among secondary school children in Oloibiri Community. International J. Trop. Diseas.\& Healt., 11(1), 1-7.

31. Fulata, M. A., Busugumu, U. A., Ngubdo, A. M., Bukama, A. M., \& Gadam, A. (2017). Determination of fluoride in some boreholes (A case of Loading [MathJax]/jax/output/CommonHTML/jax.js m. Res. J., 2(4), 42-46.

Page 13/18 
32. Ganyaglo, S. Y., Abass, G., Teye, E. M., Owosu-Ansah, E. D. J., Tettey, S., Diabene, P. Y., \& Asimah, S. (2019). Groundwater fluoride contamination and probabilistic health risk assessment in fluoride endemic areas of upper east region. Ghana. Chemosphere, 233, 862872. https://doi.org/10.1016/j.chemosphere.2019.05.276.

33. Goyit, M. P., Solomon, O. A., \& Kutshuk, R. J. (2018). Distribution of fluoride in surface and ground water: A case study of Langtang North, Plateau State, Nigeria. Int. J. Biol. Chem. Sci. 12(2), 1057-1067..

34. Ghosh, A., \& Mondal, S. (2018). Application of multivariate statistics towards the geochemical evaluation of fluoride enrichment in groundwater at Shilabati river bank, West Bengal, India. Environmental Engineering Research, 24(2), 279-288. https://doi.org/10.4491/eer.2018.178.

35. Guissouma, W., Hakami, O., Al-Rajab, A. J., \& Tarhouni, J. (2017). Risk assessment of fluoride exposure in drinking water of Tunisia. Chemosphere, 177, 102-108. DOI:10.1016/j.chemosphere.2017.03.011.

36. Gwaha, A. M. (2017). Dental fluorosis in a rural Nigerian Community: Is the water to blame? B.Sc.Thesis, Department of Natural and Environmental Sciences, American University of Nigeria, 64pp.

37. Haji, M., Karuppanan, S., Qin, D., \& Shube, S. (2021). Potential Human Health Risks Due to Groundwater Fluoride Contamination: A Case Study Using Multi-techniques Approaches (GWQI, FPI, GIS, HHRA) in Bilate River Basin of Southern Main Ethiopian Rift, Ethiopia. Archives of Environ. 10.1007/s00244-020-00802-2. Cont. \& Toxicolo. DOI.

38. Hosseini, H., Shakeri, A., Rezaei, M., Barmaki, M. D., Mehr, M., M.R (2019). Water chemistry and water quality pollution indices of heavy metals: a case study of Chahnimeh Water Reservoirs, Southeast of Iran. Int. J. Energy \& Water Resour. https://doi.org/10.1007/s42108019-00051-7.

39. Idon, P. I., \& Enabulele, J. E. (2018). Prevalence, severity, and request for treatment of dental fluorosis among adults in an endemic region of Northern Nigeria. Eur. J. Dent., 12(2), 184-190. doi:10.4103/ejd.ejd_260_17.

40. Iorliam, A. Y., Okwu, P., \& Ukya, T. J. (2013). Geotechnical properties of Makurdi shale treated with bamboo leaf ash. AU J.T, 16(3), 174180.

41. IRIS U June (2017). Integrated Risk Information System, USEPA ãuhttps://cfpubepagov/ ncea/iris/search/indexcfm?keyword = fluoride.8ã[l. Accessed 19th November, 2020.

42. Isikwue, M. O. and. Onyilo, A. F. (2010). Influence of land use on the hydraulic response of a loamy sand tropical soil. J. Emer. Trends in Eng. \& Appl. Sci, 1(2), 144-149.

43. Karunanidhi, D., Aravinthasamy, P., Subramani, T., Wu, J., Srinivasamoorthy, J., K (2019). Potential health risk assessment for fluoride and nitrate contamination in hard rock aquifers of Shanmuganadhi River basin, South India. Human \& Eco. Risk Assess.: An Int. J. https://doi.org/10.1080/10807039.2019.1568859.

44. Keta-Rokbani, M., Moncef, G., \& Bouhlila, R. (2011). ). Use of geographical information system and water quality index to assess groundwater quality in El Khairat deep aquifer Enfidha, Tunisian Sahel. Iran J, Ener. \& Env. 2, 133-144. (.

45. Magesh, N. S., Chandrasekar, N., \& Elango, L. (2017). Trace element concentrations in the groundwater of the Tamiraparani river basin, South India: Insights from human health risk and multivariate statistical techniques. Chemosphere, 185, 468-479. doi:10.1016/j.chemosphere.2017.07.044.

46. Mahamud, H. S. (2012). Pilot column studies on adsorption of fluoride onto coated high aluminium bauxite ore (HABO) and charcoal. Msc. Thesis, Department of Civil Engineering, Kwame Nkrumah University of Science and Technology. Ghana, 100pp.

47. Malago, J., Makoba, E., \& Muzuka, A. N. N. (2017). Fluoride levels in surface and groundwater in Africa: A review. Amer. J. Water Sci.\& Eng, 3(1), 1-17.

48. Malum, J. F., Onoja, S. B., \& Udochukwu, M. O. (2019). Prevalence of fluoride contamination in ground watersources in Kaltungo, Gombe State, Nigeria. Int. J. Trends in Res. \& Dev. 6(1), 2394-2403..

49. Mahmud, A., Sikder, S., \& Joardar, J. C. (2020). Assessment of groundwater quality in Khulna city of Bangladesh in terms of water quality index for drinking purpose. Appl. Water Sci., 10, 226. https://doi.org/10.1007/s13201-020-01314-z.

50. Nakazawa, K., Nagafuchi, O., Otede, U., Chen, J., Kanefuji, K., \& Shinozuka, K. (2020). Risk assessment of fluoride and arsenic in groundwater and a scenario analysis for reducing exposure in Inner Mongolia. RSC Adv. 10, 18296 - 18304. DOI: 10.1039/d0ra00435a rsc.li/rsc-advances.

51. NOAA, (2016). National Oceanic and Atmospheric Administration Climatic Report. Release 17 - 006. https://www.nasa.gov. Accessed 7th December, 2020.

52. Odjegba, E. E., Idowu, O. A., Oluwasanya, G. O., Ikenweiwe, N. B., \& Martins, O. (2014). Assessment of Water Demand and Seasonal Variation of Bacteriological Content of Public Water Systems in Abeokuta. Int. J. Inst. Ecol. Environ. Stud., 2, 81-92. 
53. Olasehinde, P. I., Amadi, A. N., Okunola, I. A., Dan-Hassan, M. A., \& Jimoh, M. O. (2016). Occurrence of fluoride and some heavy metals in groundwater from shallow aquifers near Ogbomosho, North-Central Nigeria. J. Nat. Sci. Res. 6(13), 55-60.

54. Okunola, I. A., Amadi, A. N., Olasehinde, P. I., Maspalma, S. S., \& Okoye, N. O. (2016). Quality assessment of groundwater from shallow aquifers in Hong area, Adamawa State, northern Nigeria. Ife J. Sci. 18(1), 267-283..

55. Pazand, K. (2016). Geochemisty and multivariate statistical analysis for fluoride occurrence in groundwater in the Kuhbanan basin, central Iran. Mod. Eart. Sys. \& Env. 2,72. DOI: 10.1007/s40808-016-0127-5.

56. Rafique, T., Naseem, S., Usmani, T. H., Bashir, E., Khan, F. A., \& Bhanger, M. I. (2009). Geochemical factors controlling the occurrence of high fluoride groundwater in the Nagar Parkar area, Sindh, Pakistan. J. Hazard. Mater, 171, 424-430. http://dx.doi. org/10.1016/j.jhazm.

57. Rasool, A., Xiao, T., Farooqi, A., Shafeeque, M., Masood, S., Ali, S., Fahad, S., \& Nasim, W. (2016). Arsenic and heavy metal contaminations in the tube well water of Punjab, Pakistan and risk assessment: a case study. Ecological Engineering, 95, 90-100.

58. Radfard, M., Rahmatinia, M., Akbari, H., Hashemzadeh, B., Akbari, H., \& Adibzadeh, A. (2018). Data on health risk assessment of fluoride in water distribution network of Iranshahr, Iran. Data in Brief 20, 1446-1452. https://doi.org/10.1016/j.dib.2018.08.184.

59. Ravikumar, P., \& Somashekar, R. K. (2017). Principal component analysis and hydrochemical facies characterization to evaluate groundwater quality in Varahi river basin, Karnataka state, India. Appl. Water Sci. 7, 745-755. http://dx.doi.org/10.1007/ s13201-0150287.

60. Salifu, A., Petrusevski, B., Ghebremichael, K. and Buamah, R. (2012). Multivariate statistical analysis for fluoride occurrence in groundwater in the Northern region of Ghana. J. Cont. Hydro. 140-141, 34-44. DOI: 10.1016/j.jconhyd.2012.08.002.

61. Saxena, V. K., \& Ahmed, S. (2001). Dissolution of fluoride in groundwater: a water-rock interaction study. Environ. Geol. 40, $1084-1087$. http://dx.doi.org/10.1007/ s002540100290.

62. Sellami, M., Riahi, H., Maatallah, K., Ferjani, H., Bouaziz, M. C., \& Ladeb, M. F. (2019). Skeletal fluorosis: don't miss the diagnosis! Skeletal Radiol. https://doi.org/10.1007/s0025 6-019-03302 -0.

63. Sharaf, M. A. M., \& Subyani, A. M. (2011).Assessing of Groundwater Contamination by Toxic Elements through Multivariate Statistics and Spatial Interpolation, Wadi Fatimah, Western Arabian Shield, Saudi Arabia. Int. J. Sci. \& Eng. Res., 2, 9-16..

64. Shen, J., \& Schäfer, A. I. (2015). Factors affecting fluoride and natural organic matter (NOM) removal from natural waters in Tanzania by nanofiltration/reverse osmosis. Sci. Total Environ. 527- 528, 520-529. http://dx.doi.org/10.1016/j.scitotenv.2015.04.037.

65. The World Gazetteer (2020). Archived from the original on 14th September, 2018. Retrieved 6th April 2020.

66. Tirkey, P., Bhattacharya, T., Chakraborty, S., \& Baraik, S. (2017). Assessment of groundwater quality and associated health risks: a case study of Ranchi city, Jharkhand, India. Groundw. Sustain. Dev. 5, 85-100. http://dx.doi.org/10.1016/j.gsd.2017.05.002.

67. Uriah, L. A., Dibal, H., \& Schoeneich, K. (2014). Fluoride in groundwater in Nigeria: Origin and human health impact. Amer. J. Environ. Protect., 3(6), 66-69.

68. USEPA, (2011). Exposure Factors Handbook: 2011 Edition, U.S. Environmental Protection Agency, USA. https://doi.org/EPA/600/R090/052F.

69. WHO. (2017). Guidelines for drinking water quality, 4th edition incorporating the first addendum. Swizerland: Geneva.

70. WHO, (2008). Guidelines for drinking water quality, 3rd edition Vol. 1, Geneva, Switzerland.

71. WHO. (2004). The world health report: Changing history. Switzerland: Geneva.

72. Yousefi, M., Ghoochani, M., \& Mahvi, A. H. (2018). Health risk assessment to fluoride in drinking water of rural residents living in the Poldasht city, Northwest Iran. Ecotoxi. \& Environ. Safety, 148, 426-430. http://dx.doi.org/10.1016/j.ecoenv.2017.10.057.

\section{Figures}




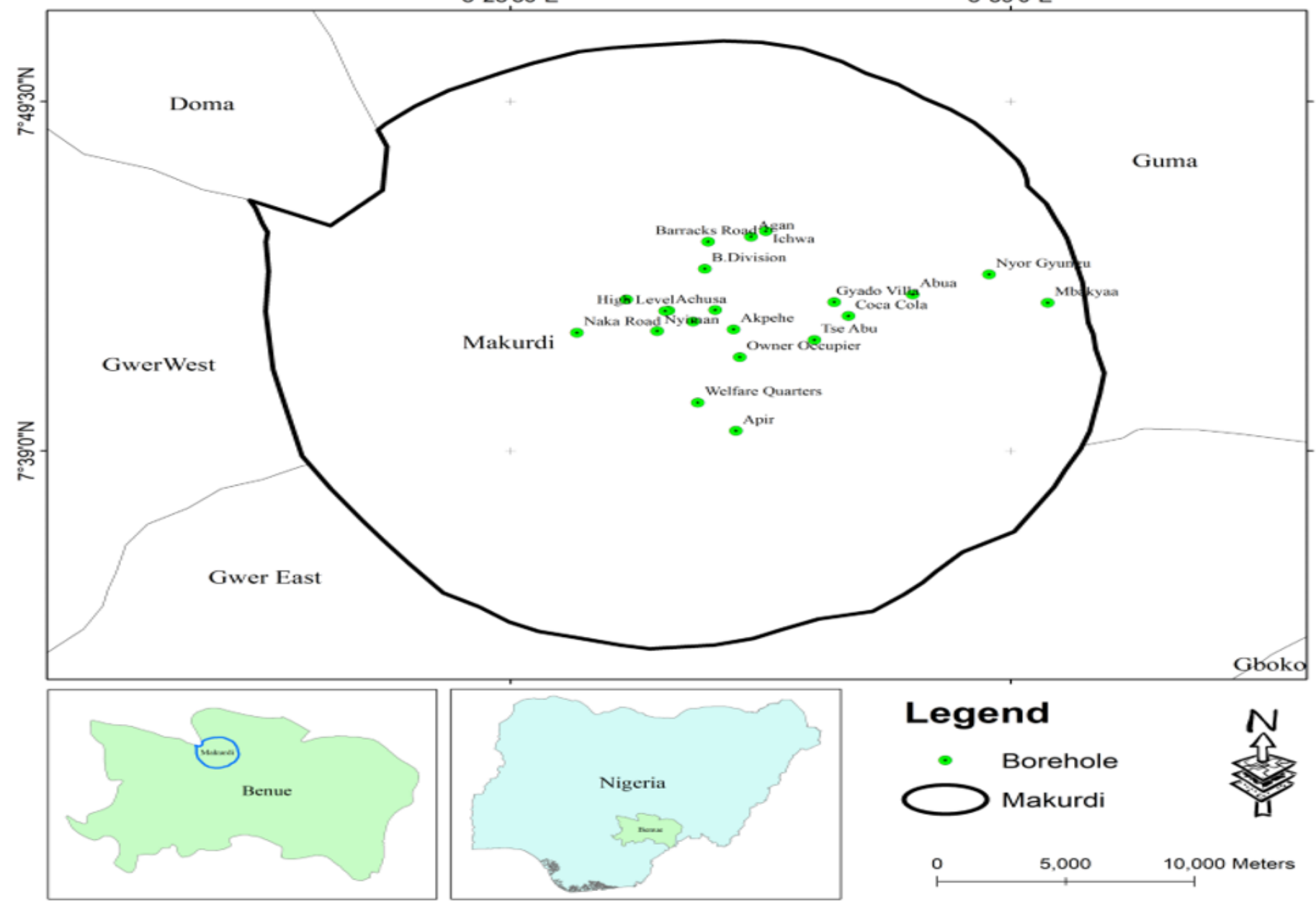

\section{Figure 1}

Map of Study Area showing the sampling points. Note: The designations employed and the presentation of the material on this map do not imply the expression of any opinion whatsoever on the part of Research Square concerning the legal status of any country, territory, city or area or of its authorities, or concerning the delimitation of its frontiers or boundaries. This map has been provided by the authors. 

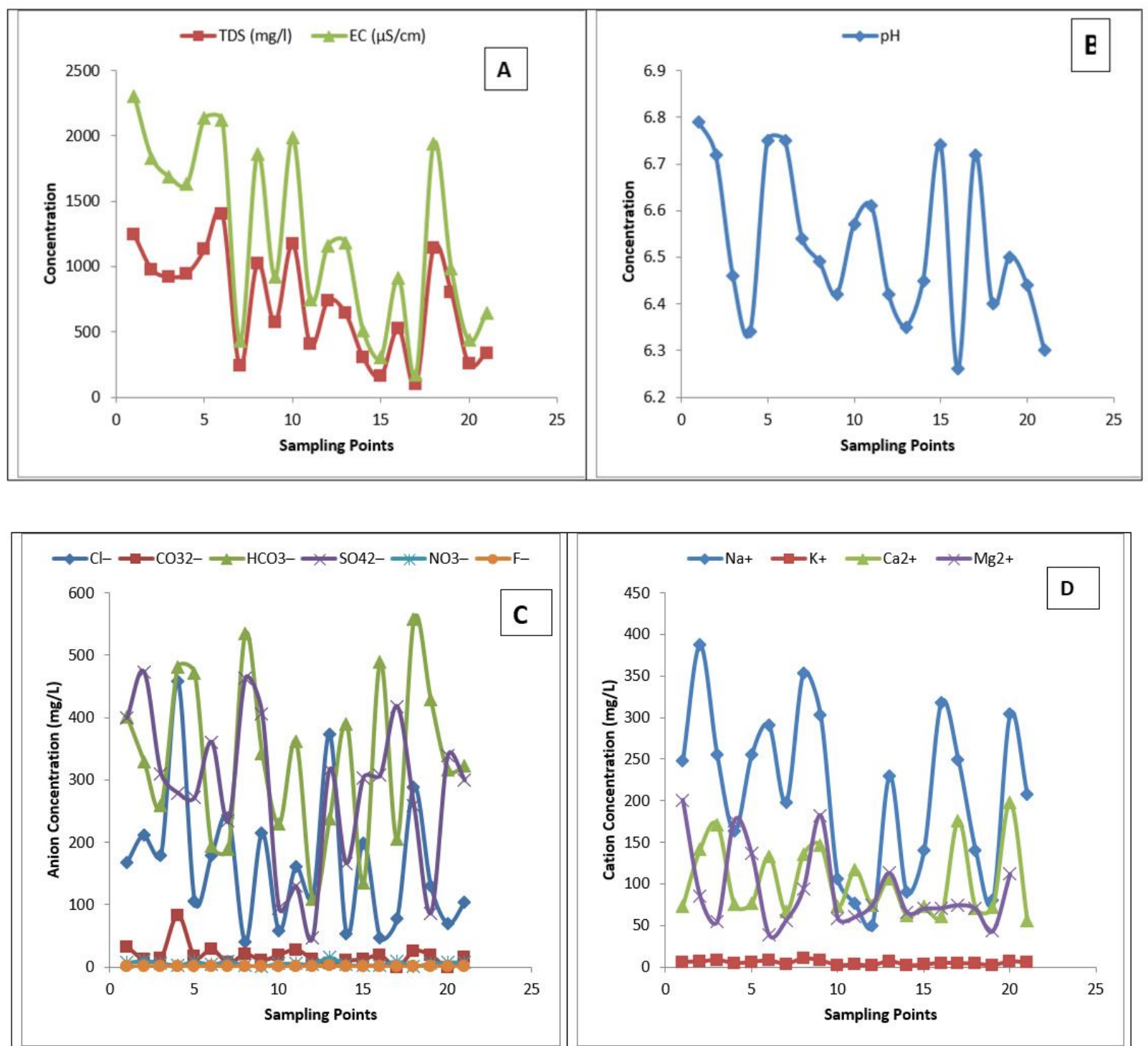

Figure 2

Spatial Variation of Physico-chemical Parameters (a): pH, (b): TDS and EC, (c): Anions and (d): Cations 


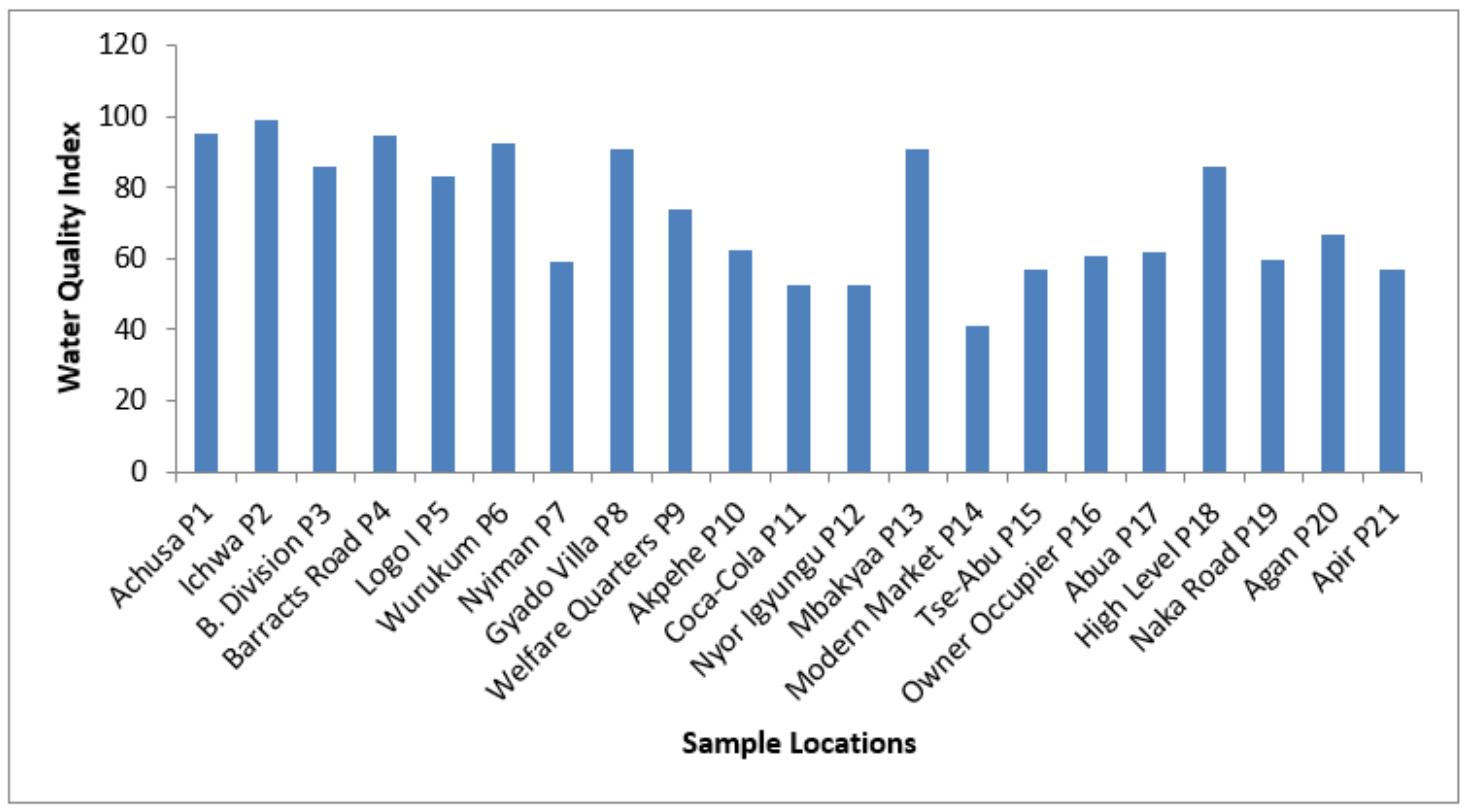

Figure 3

Water Quality Index (WQI) for the Studied Locations

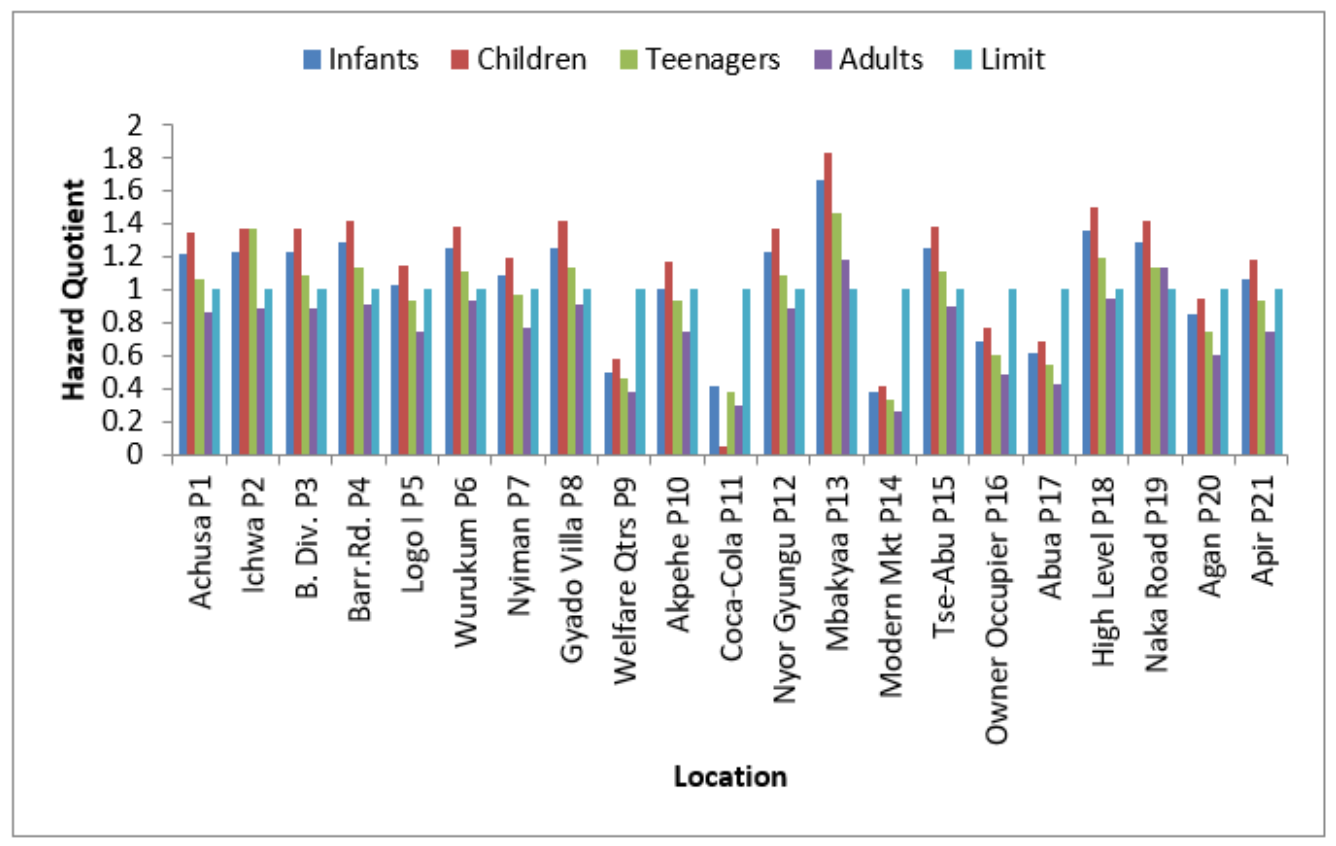

Figure 4

Hazard Quotient for Fluoride Risk in the studied Populations

\section{Supplementary Files}

This is a list of supplementary files associated with this preprint. Click to download.

- SupplementaryMaterialforEnvMonAssess.docx 